\title{
The One-Tel Collapse: Lessons for Corporate Governance
}

\author{
Reza Monem \\ Dept of Accounting, Finance and Economics \\ Griffith University \\ 170 Kessels Road \\ Nathan, QLD 4111 \\ Australia
}

Email: r.monem@griffith.edu.au

Phone: +61-7-373 53598 (Australia)

\begin{abstract}
:
One-Tel was a major corporate collapse in Australia in 2001. At the time of its collapse, it was the fourth largest telecommunications company in Australia with more than two million customers and operations in eight countries. Analyses of quantitative and qualitative data from diverse sources suggest that One-Tel's collapse is a classic case of failed expectations, strategic mistakes, wrong pricing policy, and unbridled growth. The company's meteoric rise and fall was associated with serious deficiencies in its corporate governance including weaknesses in internal control, financial reporting, audit quality, board's scrutiny of management, management communication with the board, and poor executive pay-toperformance link. Thus, the collapse of One-Tel has several important lessons on the role of corporate governance in preventing corporate collapse.
\end{abstract}

JEL classification: M41

\section{Brief biography:}

Reza Monem is Associate Professor of Accounting at Griffith University, Nathan Campus. He holds a PhD from the University of Queensland and a Master of Accounting Science from the University of Illinois at Urbana-Champaign. He is a CPA and a CMA. Reza's research work has been published in several journals including Contemporary Accounting Research, Accounting and Finance, Pacific Accounting Review, Australian Accounting Review, Finance India, Accounting Business \& Financial History, Corporate Ownership \& Control, and Journal of Business Administration. He is a past member of the Editorial Review Board of The International Journal of Accounting (USA) and currently a Co-Editor of Accounting, Accountability \& Performance. 


\section{The One-Tel Collapse: Lessons for Corporate Governance}

\section{Introduction}

This is a case study on the collapse of One-Tel. ${ }^{1}$ At the time of its collapse in May 2001, One-Tel was the fourth largest telecommunications company in Australia. It had more than two million customers and operations in eight countries. One-Tel's collapse came as a shock to the corporate world in Australia (Australian Broadcasting Corporation 2001, Cooke 2001). Among the major corporate collapses of 2001 in Australia, the collapse of HIH Insurance has been studied (e.g., Mak, Deo and Cooper 2005; Mirshekary, Yaftian and Cross 2005). However, there is no academic research on the One-Tel collapse. Using evidence in One-Tel, this paper demonstrates that weaknesses in governance practice in relation to internal control system, financial reporting quality, audit quality, management scrutiny, management communication with the board, and the executive pay-to-performance link can be catalysts to corporate collapse.

Research on corporate collapse has mainly focused on developing and testing bankruptcy prediction models (e.g., Ohlson 1980, Houghton 1984, Lennox 1999, Charitou and Neophytou 2004, Jones and Hensher 2007). Moreover, bulk of the corporate governance research deals with only healthy firms to understand the role of corporate governance in different contexts such as firm performance (e.g., Bhagat and Bolton 2008, Brown and Caylor 2009), executive compensation (e.g., Core, Holthausen and Larcker 1999; Cyert, Kang and Kumar 2002), corporate structure (Lemmon and Lins 2003, Holstrom and Kaplan 2001) and firm value (e.g., Brown and Caylor 2006; Morey, Gottesman, Baker and Godridge 2009).

While corporate governance receives wide media and political attention following major collapses, academic research has rarely addressed corporate governance in collapsed firms. This paper aims to fill some of this void. If society expects corporate regulators to design, and businesses to practice governance structures that are likely to reduce the chances 
of corporate collapse, then analysis of governance structure and practice of collapsed firms is in order.

To draw lessons from the One-Tel collapse, this paper first provides a brief history of the company (section 2). Understanding its business history in terms of the business model, strategies and growth is important for identifying the antecedents to its collapse. Then, to document its financial distress and subsequent collapse, One-Tel's financial performance is analysed (section 3). Thereafter, governance practice at One-Tel is analysed for linking its collapse with corporate governance (section 4). Finally, summary and conclusions of the paper are provided (section 5).

In terms of design, it is an embedded, single-case study (Creswell 2007, Yin 2003). Both archival quantitative and qualitative data were analysed. Analysis of archival data mitigates observer-caused effects and observer bias (McKinnon 1988). To ensure the reliability of data sources (McKinnon 1988), qualitative data were collected from diverse sources such as company annual reports, legal judgment, newspaper articles, and published electronic media contents. Further, as data were collected from diverse sources, the study achieves some level of data triangulation (Creswell 2007, Stake 1995). Qualitative data were analysed and interpreted using textual analysis method (Bryman and Bell 2007, Tregidga and Milne 2006) and by following an iterative process as suggested by Mäkelä and Näsi (2009). The quantitative analysis was longitudinal in nature. It involved analysis of One-Tel's audited financial statements for the fiscal years 1996-97 to 1999-2000 as well as a comparison of One-Tel's performance against its competitors. The next section provides a brief history of the One-Tel collapse.

\section{The One-Tel Collapse}

One-Tel was launched on 1 May 1995. Under an agreement with Optus which was the second largest telecommunications company in Australia, One-Tel received SIM cards, customer call details, and network service from Optus. One-Tel had to pay Optus for the call charges and a 
monthly access fee for each of its subscribers. Thus, One-Tel's gross profit was the excess of the amount billed to its customers over the amount paid to Optus. The company hoped to attract customers by offering cheap mobile calling rates, and selling profitable, long distance and international call service to them.

The company grew very rapidly in its early years. Its customer base increased from only 1000 on 30 June 1995 to 100000 by 28 September 1996 to 160000 by 30 June 1997 . Its sales revenue was $\mathrm{A} \$ 148$ million in 1996-97 with an operating profit after tax of $\mathrm{A} \$ 3.7$ million. However, disputes developed between Optus and One-Tel since July 1996 on two issues: (1) Optus was directly competing with One-Tel for subscribers; and (2) whether OneTel's customers were entitled to Optus' reduced price offers (Australian Securities and Investment Commission (ASIC) v. Rich [2009], NSWSC 1229).

In July 1997, One-Tel signed an agreement with Global One, which enabled One-Tel to provide discounted national and international calls to its customers carried on Global One’s network. On 13 November 1997, One-Tel was listed on the Australian Stock Exchange (ASX) at an issue price of A\$2 (The Australian 14 November 1997: 24). By the end of December 1997, One-Tel had over 200000 customers and over 400 dealers across Australia (ASIC v. Rich [2009], NSWSC 1229).

In January 1998, the company launched its 'Global Strategy' to expand into Europe and the United States (US). Throughout 1998, it opened offices in Los Angeles, London, Paris, Hong Kong and Amsterdam for the sale of fixed wire services. In September 1998, One-Tel acquired $2.5 \mathrm{MHz}$ of spectrum in both Sydney and Melbourne and $5 \mathrm{MHz}$ of spectrum in each city of Brisbane, Adelaide and Perth for a total amount of A\$9.5 million (ASIC v. Rich [2009], NSWSC 1229). Since January 1998, One-Tel’s share price continually increased to reach A\$9.8 on 14 February 1999.

On 15 February 1999, News Ltd and PBL, through a series of complex arrangements, agreed to invest $\mathrm{A} \$ 430$ million each immediately and another $\mathrm{A} \$ 280$ million in future in 
exchange of 40 per cent of the shares. The idea was for News Ltd and PBL to work together to build the leading mobile phone network in Australia with two million subscribers by December 2004 (ASIC v. Rich [2009], NSWSC 1229, p. 504). Investors responded positively to the 15 February deal. The share price had increased from A $\$ 9.8$ on 14 February 1999 to A $\$ 12.63$ in two days. The strategy to build the leading mobile phone network involved developing One-Tel’s ‘Next Generation’ mobile network, expanding One-Tel’s Internet business, expanding fixed wire business in Europe and Hong Kong, continuing as reseller of Optus services, and competing with Telstra for fixed wire business (ASIC v. Rich [ 2009], NSWSC 1229, p. 504).

One-Tel launched it local call product in late 1999, charging subscribers at a rate of Australian 17.5 cents as part of a bundled product that included fixed to mobile calls, national and international calls. While the local calls would operate at a loss, the expectation was that the relatively high margins on the other bundled products would counter that loss and allow for a net positive margin (ASIC v. Rich [2009], NSWSC 1229). In September 1999, One-Tel signed an agreement with Lucent Technologies to build an Australian national mobile network at a cost of $\mathrm{A} \$ 1.15$ billion. Later, disputes surfaced between the two companies surrounding significant delays in building the network and other matters. However, on 23 November 1999, Lucent Technologies announced that it would build and finance a European mobile network at a cost of US\$20 billion for One-Tel to service its European customers. On the same day, One-Tel was ranked as the 30th largest listed company in Australia with a market capitalisation of A \$3.8 billion (Barry 2002). On 26 November 1999, One-Tel shares hit a new record of A $\$ 2.84$ making the company worth A $\$ 5.3$ billion (Barry 2002). ${ }^{2}$

To keep pace with its ambitious growth plan, One-Tel's expenses for employees and suppliers grew phenomenally: A \$98.71 million in 1996-97, A \$193.35 million in 1997-98, A \$328.11 million in 1998-99, and A\$648.80 million in 1999-2000. At the same time, OneTel's cash outlay for acquiring non-current assets was A $\$ 4.9$ million in 1996-97, A $\$ 10.8$ 
million in 1997-98, A $\$ 32.2$ million in 1998-99, and A $\$ 614.9$ million in 1999-2000. The 1999-2000 expenditures included A \$523 million for purchasing telecommunication licences in March 2000. This amount was ten times of what Optus, Vodafone, and Telstra had paid for acquiring similar licences in the immediate past (Barry 2002).

In August 2000, the company announced a record operating loss of A \$291 million for the 1999-2000 fiscal year despite the doubling of sales revenue from the previous year to A \$654 million. In October 2000, the merchant bank Merrill Lynch warned that One-Tel was in danger of running out of cash. By January 2001, One-Tel’s Next Generation network was 90\% completed in all State capitals except Melbourne, where it was 54\% complete. Around this time, One-Tel's customer acquisition cost (comprising marketing costs, handset subsidy and dealer commission) per customer on the Next Generation network was $\mathrm{A} \$ 350$ and monthly gross margin per customer was A\$50 (ASIC v. Rich [2009], NSWSC 1229, p. 506). Thus, it required approximately seven months from signing up of a customer just to recover the customer acquisition cost.

In February 2001, the company revealed that it lost A $\$ 132$ million over JulyDecember 2000, and Merrill Lynch forecasted that One-Tel would run out of cash by April 2001. By March 2001, its cash reserves fell to A\$35 million. On 19 April 2001, the company’s cash balance dropped to A $\$ 25$ million. On 16 May 2001, the two joint-CEOs Jodee Rich and Brad Keeling agreed to resign. On 18 May 2001, Rodney Adler, one of the non-executive directors, sold his six million shares in One-Tel for A $\$ 1.21$ million. This sale was in addition to five million shares he had sold in February 2001. One-Tel's cash crisis deepened with the unwillingness of News Ltd and PBL, its two largest shareholders, to provide any additional capital. On 29 May 2001, One-Tel’s auditor Ernst and Young estimated that the company needed another $\mathrm{A} \$ 240$ to $\mathrm{A} \$ 370$ million to stay afloat for the next six months. The company went into receivership on 30 May 2001. Meanwhile, on 25 May 2001, the last trading day for One-Tel, its shares closed at Australian 16 cents. In fact, 
One-Tel's share price had continued to slide downward from the November 1999's record high until the last trading day. Later on 24 July 2001, the creditors of the company voted to wind up its operations (Owen, 2001). In the next section, One-Tel's financial performance is analysed.

\section{Financial Performance}

The 1998 Annual Report ${ }^{3}$ of One-Tel stated, 'One-Tel has the customer numbers required to maintain profitability and fund sustainable subscriber growth' (p. 36) [emphasis added]. However, an analysis of its financial performance vis-à-vis customer growth would suggest otherwise. Table 1 summarises key performance indicators and financial variables of One-Tel for the period 1996-97 to 1999-2000. The firm's sales revenue showed successive growth to reach A $\$ 653.4$ million in 1999-2000, which was ten times of the sales revenue in 1995-96. In particular, it sales revenue had a year-on-year increase of 127\% in 1996-97, 40\% in 1997-98, $57 \%$ in $1998-99$ and $100 \%$ in $1999-2000$. However, the phenomenal revenue growths did not translate into higher profitability. One-Tel’s profit margins (operating profit after tax divided by sales revenue) appeared to be $3 \%$ in $1996-97,3 \%$ in $1997-98,2 \%$ in $1998-99$ and $-45 \%$ in 1999-2000. Similarly, its returns on assets (operating profit after tax scaled by total assets at the beginning of the year) were $12 \%$ in $1997-98,9 \%$ in $1998-99$ and $-55 \%$ in $1999-2000$.

\section{TAKE IN TABLE 1 ABOUT HERE}

One-Tel's cash flows over the period 1996-97 to 1999-2000 are summarised in Table 2. One-Tel's 1998 Annual Report (p. 11) claimed that the company was cash flow positive from normal operations. However, Table 2 reveals that One-Tel collected (paid) A $\$ 113.2$ (A \$98.7) million, A\$186.5 (A $\$ 193.3)$ million, $\mathrm{A} \$ 300.1$ (A $\$ 328.1)$ million and $\mathrm{A} \$ 510.9$ (A\$684.8) million from customers (to suppliers and employees) for the years 1996-97, 199798, 1998-99 and 1999-2000, respectively. Thus, after 1996-97, One-Tel's cash flow from operations had never been positive. By comparison, One-Tel reported operating profit (loss) after tax of A\$5.9 million in 1997-98, A \$6.9 million in 1998-99 and A $\$(291.1)$ million in 
1999-2000 (see Table 1). Although sales revenue had been increasing each year, One-Tel was not collecting cash fast enough to finance the aggressive corporate expansions. For instance, 82\% (80\%) of annual incremental sales revenue in 1997-98 (1998-99) was collected in cash within the same fiscal year. This ratio dramatically dropped to 55\% in 1999-2000. On the other hand, One-Tel was making ever-increasing cash payments to suppliers and to a growing pool of employees. One-Tel had 300 employees in June 1997. By June 1999, it had 1163 employees. By June 2000, the number had more than doubled to 2485.

\section{TAKE IN TABLE 2 ABOUT HERE}

One-Tel's marketing and advertising campaigns created an impression that the company was targeting ‘the back-packing community’ (The Financial Times 16 June 2000: 26). Further, the company relaxed its credit standards when signing up new customers, and credit checks were overridden sometimes (ASIC v. Rich [2009], NSWSC 1229, p. 532). Thus, although its mobile-phone customers increased from 75000 in 1995-96 to 290000 in 1997-98 to 730000 at the end of 1999-2000, the accelerated growth in customers came at the expense of profitability. First, as shown in Figure 1, its sales revenue per customer dropped from $\mathrm{A} \$ 933$ in $1996-97$ to $\mathrm{A} \$ 715$ in $1997-98$ to $\mathrm{A} \$ 508$ in 1998-99. Second, as shown in Figure 2, its sales revenue per customer per day went down from A\$2.56 in 1996-97 to A \$1.96 in 1997-98 to A $\$ 1.39$ in 1998-99 but increased to A $\$ 2.45$ only in 1999-2000. By comparison, cash paid to employees and suppliers per customer per day amounted to A $\$ 1.70$ in 1996-97, A $\$ 1.83$ in 1997-98, A \$1.40 in 1998-99 and A $\$ 2.57$ in 1999-2000. Thus, clearly One-Tel was pricing its services even below its 'cash costs' for at least 1998-99 and 19992000. Further, when change in sales revenue is divided by change in the number of customers, it appears that every new customer on average generated a revenue of only A \$0.9869 in 1996-97, A $\$ 0.4507$ in 1997-98, A\$0.3371 in 1998-99 and A $\$ 3.7206$ in 19992000. Thus, One-Tel was clearly attracting low quality, low-value customers who did not make phone calls. 


\section{TAKE IN FIGURE 1 ABOUT HERE}

One-Tel's operating net cash flow per customer per day had been worsening over the years from Australian 23.09 cents in $1996-97$ to -7.56 cents in $1997-98$ to -12.35 cents to 63.39 cents in 1999-2000. Even if its accounts receivable had been fully collected within the same fiscal year, on a cash basis One-Tel would have reported a loss of A \$2.1 million in 1998-99 and a further loss of A $\$ 31.4$ million in 1999-2000. Thus, One-Tel was clearly pricing its services below costs even on a cash basis.

\section{TAKE IN FIGURE 2 ABOUT HERE}

To explore whether its financial performance represented the state of the telecommunications industry in Australia during the late 1990s, Table 3 compares the performance of One-Tel against that of Optus, AAPT and Hutchison Telecommunications (Australia) Ltd over the period 1998-2000. Clearly, Optus and AAPT improved their performance from operating loss after tax of $\mathrm{A} \$ 95.4$ million and $\mathrm{A} \$ 16.80$ million in 1998 to operating profit after tax of $\mathrm{A} \$ 264$ million and $\mathrm{A} \$ 38.20$ million in 2000, respectively. On the other hand, One-Tel's performance declined from an operating profit after tax of A $\$ 5.9$ million in 1998 to an operating loss after tax of A\$291.1 million in 2000. One-Tel’s return on assets (operating profit after tax divided by total assets at year end) went down from $8 \%$ in 1998 to $-20 \%$ in 2000 whereas AAPT's return on assets improved from $-5 \%$ in 1998 to 5\% in 2000. Optus also showed improvement similar to that of AAPT, while Hutchison's performance was volatile ranging from $-23 \%$ in 2000 to $22 \%$ in 1998 . However, one has to consider that Hutchison was the youngest operator among these four companies and only entered the market in 1999. AAPT and One-Tel both began their operations in 1995. Thus, unlike its competitors, One-Tel's profitability had been worsening over time in a telecommunications market that had been growing due to deregulation and increasing demands for mobile phone service. The next section deals with One-Tel's corporate governance. 


\section{TAKE IN TABLE 3 ABOUT HERE}

\section{Corporate Governance}

To examine the role of One-Tel's corporate governance in its collapse, one needs to define corporate governance and the standards of measuring the quality of governance. Shleifer and Vishny (1997: 737) define corporate governance as 'the ways in which suppliers of finance to corporations assure themselves of getting a return on their investment'. Effective corporate governance requires an environment in which 'authority is exercised with absolute probity' (Clark and Dean 2007: 64). It requires directors, executive and non-executive, to ask awkward questions and for the board chair to ensure a proper flow of information to the board of directors (Clarke and Dean 2007).

O’Shea (2005) observes that good governance has six universally accepted practices, implicitly or explicitly: (1) a balance of executive and non-executive directors; (2) a clear division of responsibilities between the board chair and the chief executive officer; (3) provision of timely and quality information to the board; (4) formal and transparent procedures for the appointment of new directors; (5) balanced and understandable financial reporting; and (6) maintenance of a sound internal control system. Oshea's observations are consistent with the ASX Corporate Governance Council (CGC)'s good governance recommendations. According to ASX CGC (2003), good corporate governance requires (1) establishing clear roles of management and the board; (2) balancing between skills, experience and board independence; (3) integrity of and responsible decision-making by senior managers; (4) integrity of company reporting; (5) timely and balanced picture of all material events; (6) recognition of shareholder rights; (7) managing risk through oversight and internal control; (8) formal mechanisms to encourage board and management effectiveness; (9) remunerating management fairly and responsibly; and (10) recognising the legitimate interests of stakeholders. 
When the standards of good governance are applied to One-Tel, it would appear that many of its practices did not comply with good governance. More importantly, governance failure exacerbated the conditions in which One-Tel collapsed. The next three sub-sections focus on three aspects of One-Tel's corporate governance: financial reporting quality, board composition and activity, and executive compensation.

\subsection{Financial reporting quality}

Financial reporting quality is high when financial reports faithfully represent the underlying economic phenomena. Faithful representation requires financial information to be complete, neutral (i.e., unbiased presentation of both good and bad news) and free from error (Statement of Financial Concepts No. 8, FASB, 2010). This broad definition encompasses earnings quality. Higher earnings quality faithfully represents the features of the firm's fundamental earnings process (Dechow, Ge and Schrand 2010). This section documents that One-Tel's financial reporting did not faithfully represent its economic performance and thus was of lower quality.

It is highly unlikely that One-Tel's financial statements were free from errors. In ASIC v. Rich (2009, NSWSC 1229), Jodee Rich gave evidence that he did not typically see, inter alia, One-Tel's trial balances, spreadsheets underlying monthly board reports, reports on ageing of debtors and creditors, to-be-billed reports, and unpresented cheque listing (p. 257). He relied on other responsible managers to bring matters to his attention (p. 258). Similar to Jodee Rich, Mark Silbermann, the finance director since July 1997, has rarely seen One-Tel's ledgers, journals, trial balances or other primary or secondary accounting records (p.260). There were discrepancies in several records and documents including monthly trial balances (ASIC v. Rich [2009], NSWSC 1229, p. 301), collection of accounts receivable (p. 303, 313, 315), data description (p. 309), the outstanding balance of accounts receivable (p. 316) and reporting of EBITDA (p. 286). One-Tel did not have real-time or close to real-time information about total debtors, ageing, and risk profile of debtors (ASIC v. Rich [2009], 
NSWSC 1229, p. 314). All these matters suggest weaknesses in One-Tel's internal control system. At One-Tel, the accuracy and integrity of financial records and data apparently did not receive the highest priority from senior management.

There are several reasons to believe that One-Tel's earnings were of low quality. First, One-Tel had higher accrual component in its earnings relative to that of its competitors with similar size. ${ }^{4}$ Because accruals are subject to management manipulation, high proportion of accruals in earnings would suggest low quality of earnings. For example, both in 1998 and 1999, One-Tel had positive earnings because of large positive accruals amounting to $18 \%$ and 7\% of total assets, respectively. On the other hand, Optus and Hutchison always had negative income-decreasing accruals. AAPT had positive accruals for 1999 and 2000 but at least it had positive operating cash flows for both years. Thus, clearly, One-Tel's earnings were of lower quality relative to that of its competitors.

Second, One-Tel made two major accounting policy changes (one mandatory and one voluntary) over a period of two years. The 1998 Annual Report stated, 'In contrast to most telecommunication companies, our conservative accounting does not create intangibles in our balance sheet' (p. 6). However, in 1999, the company changed its policy regarding deferred expenditures. Previously expensed costs of the establishment of business operations were now capitalised for amortisation over a period not exceeding three years. If these costs had to be written off in full in the year incurred, the reported operating profit in 1998-99 would have been reduced by A\$32.4 million (One-Tel Annual Report 1999: 18) and reported earnings per share of 0.52 cent would have turned into a loss per share of two cents. Next year One-Tel reported a record operating loss after tax of A $\$ 291.1$ (before tax loss of A $\$ 295.9$ ) million. This after tax loss was 15.57 times of the cumulative after tax profits of A $\$ 18.7$ million of the all the past years. This loss was also 41.59 times of the operating profit after tax reported in the previous year. One-Tel blamed this loss largely on the change in accounting policy in relation to 'the establishment of business operations and subscriber acquisitions' (One-Tel 
Annual Report 2000: 16). In fact, the company had to write off these costs as per the UK GAAP because of One-Tel's proposed listing at the London Stock Exchange. Although OneTel chose to capitalize such costs previously under the Australian GAAP, the writing off approach was always consistent with the Australian GAAP. Moreover, if this policy change had not been required, One-Tel's operating profit before tax would have been reduced by A \$173.2 million in 1999-2000. Thus, One-Tel's operating profits reported in all the past years were largely due to non-conservative accounting policy choices.

Third, in the management discussion and analysis (MD\&A) in all annual reports, One-Tel's management emphasised on earnings before interest, depreciation, taxes and amortisation (EBIDTA) instead of the earnings reported under GAAP. Focusing on EBIDTA creates an illusion that interest expense, depreciation, amortisation and taxes are only accounting expenses. For example, the 1998 Annual Report contains a graph comparing the growth in EBITDA from A\$3.9 million in 1995-96 to A $\$ 10.6$ million in 1997-98 (p. 8). EBIDTA is used mainly by companies that report lower than expected earnings and start-up companies that are operating at a loss (King 2001). Its usefulness as a non-GAAP performance metric is questionable (Francis et al. 2003, Jennings 2003).

It would appear that the audit quality for One.Tel was low. Following Carey and Simnett (2006), audit quality in this paper is defined on two dimensions:(1) the auditor's propensity to issue a going-concern opinion, and (2) the level of abnormal accruals in earnings (an indication of earnings management). Non-compliance with accounting and auditing standards while issuing unqualified audit opinion also suggests low-quality audit. From 1997 to 2000, One-Tel was audited by the same audit firm, BDO Nelson Parkhill (BDNP). The auditor issued unqualified audit opinions for all these years. Submission of the 1998-99 financial statements to the ASIC revealed that the company had deferred A \$48 million of expenditure and a loss of more than $\mathrm{A} \$ 40$ million had been concealed (Barry 2002). Subsequently, the Institute of Chartered Accountants of Australia (ICAA) examined 
the One-Tel financial reports and identified 48 items of concern. The audit partner in charge of One-Tel and BDNP were both reprimanded by the ICAA. BDNP was fined A $\$ 48000$ as well. The ICAA also concluded that the audit report was in breach of the Corporations Law, Australian accounting standards and Australian auditing standards (Barry 2002). In January 2001, One-Tel switched it auditor. The new auditor, Ernst \& Young, complained to OneTel's senior management that provisions for bad debts had been too low (Barry 2002).

One.Tel had worsening operating cash deficits (e.g., A\$(8) million in 1997-98, A \$(28.9) million in 1998-99, A\$(168.9) million in 1999-2000), customer billing and cash collection problems (Clarke, Dean and Oliver 2003), and employed large positive accruals and non-conservative accounting policies to minimise losses. However, BDNP never issued a going concern opinion. There is further evidence that One-Tel purchased a lot of non-audit services (NAS) from its external auditor. The non-audit fees as a proportion of the total fees paid to the auditor were $41 \%$ in $1996-97,54 \%$ in $1997-98,52 \%$ in $1998-99$ and $46 \%$ in 1999 2000. If being engaged in NAS with a client firm provides useful insight into the evaluation of a client's internal control, the planning of audit, and the prosecution of it (Clarke and Dean 2007), it is unclear whether the audit quality in One-Tel improved at all as a result of the NAS.

The evidence presented here suggests that One-Tel's reported earnings did not faithfully represent its fundamental earnings process. Its financial reporting quality including earning quality was low. It is no surprise that audit quality in One.Tel was low as well, given that financial reporting quality is endogenously related to audit quality. Low financial reporting quality and low audit quality concealed One-Tel's real financial performance and financial distress from its board and the shareholders. This in turn blocked any opportunity for remedial actions to avoid corporate collapse. The above discussion leads to the following hypotheses: 
$\mathrm{H}_{1}$ : Ceteris paribus, firms with weaker internal control systems than others are more likely to collapse.

$\mathrm{H}_{2}$ : Ceteris paribus, firms with lower financial reporting quality than others are more likely to collapse.

$\mathrm{H}_{3}$ : Ceteris paribus, firms with lower audit quality than others are more likely to collapse.

\subsection{Board composition and activity}

Analysis of the 1998 Annual Report suggests, One-Tel had four members in the board that year with Jodee Rich and Brad Keeling acting as joint managing directors (chief executive officers). Rodney Adler and John Greaves were the two non-executive directors with the latter acting as the board chair. All board members were subject to election each year except Jodee Rich. This ensured that he always remained as a chief executive officer (CEO). Both Jodee Rich and Brad Keeling held CEO positions until their resignation in May 2001. John Greaves remained as the board chair until his resignation in March 2001.

At the end of June 1999, One-Tel's board comprised eight members, which included five non-executive directors. The Audit Committee of 1997-98 and 1998-99, the Finance and Audit Committee of 1999-2000, the Remuneration Committee of 1999-2000, and the Corporate Governance Committee of 1999-2000 were all comprised of the same two nonexecutive directors, Rodney Adler and John Greaves, who had close links with the CEOs. This is despite the fact that One-Tel had three other non-executive directors for part of 199899 and the whole of 1999-2000. Further, since an audit committee should ensure compliance with the accounting standards (Clarke et al. 2003), One-Tel's breach of accounting standards in its 1998-99 financial statements could be viewed as ineffectiveness of its audit committee.

In One.Tel, the board chair did not always preside over board meetings. In 1997-98, one of the CEOs was appointed as chair for one of the eight meetings held in the year. In 1998-99, the board chair attended seven of the 10 meetings held but presided over only four. Of the remaining six meetings, four were presided by Jodee Rich, one presided by Brad 
Keeling, and one presided by Mark Silbermann who was the finance director and company secretary. During 1999-2000, John Greaves attended all the 12 board meetings held but presided over 10 meetings. Of the remaining two, Jodee Rich chaired one meeting and the finance director chaired the other meeting. Thus, responsibilities between the board chair and the management were not clearly defined. This is inconsistent with the ASX good governance guidelines (ASX CGC 2003). Further, chairing of the board meetings frequently by a CEO suggests his excessive influence and dominating role in the board. In contrast, good corporate governance requires that there should be a balance of authority so that no single individual has unfettered powers (ASX CGC 2003).

Full disclosure of corporate affairs is vital for effective functioning of a board. Substantive evidence exists to suggest that One-Tel's case was far from the ideal. Lack of full disclosure may have indirectly contributed to the non-executive directors' ability to monitor the management. For example, although One-Tel had a practice of producing monthly 'flash' reports for circulation to directors that covered revenue, gross margin, operating expenses and EBITDA, such reports did not routinely include cash balances and did not provide any information with respect to outstanding creditors, outstanding trade receivable or the ageing of debtors (ASIC v. Rich [2009], NSWSC 1229, p. 284). One-Tel's bi-monthly board meeting papers included information on cash balance and monthly cash usage, but the cash balances never took into account unpresented cheques or any amounts unavailable for general operations (ASIC v. Rich [2009], NSWSC 1229, p. 287). Management never clarified that such balances excluded unpresented cheques, and no director ever enquired about the exact cash balance available (ASIC v. Rich [2009], NSWSC 1229, p. 1192-1193). In his verdict, Justice Austin observed that 'It does not appear that the specific level of Australia or international creditors at any particular time, or movements in the figures, were disclosed to the directors in board papers or flash reports, or in conversations with the defendants. Conversely, however, it does not appear that they asked 
for such information' (ASIC v. Rich [2009], NSWSC 1129, p. 1201). Further there were aspects of the financial position at the end of February 2001 that were not expressly disclosed to the directors as a whole (ASIC v. Rich [2009], NSWSC 1129, p. 1207). Justice Austin on several occasions was critical of the non-executive directors' lack of scrutinising One-Tel management. For example, he commented, '[T]he interaction between the board and management in the decision-making process is not a one-way interaction: a director wishing to compare the half-yearly result with the unamended ... budget but lacking current access to the figures could and should have asked the chairman to obtain such information, or have directly asked for it during the presentation at the board meeting' (ASIC v. Rich [2009], NSWSC 1129, p. 1205).

Most of the non-executive directors that One.Tel had would not have qualified as ‘independent directors' under the ASX CGC (2003) recommendations since the directors had substantial investments in the company. Further, evidence provided in ASIC v. Rich (2009, NSWSC 1229) suggests that there was a lack of diversity of opinions in the board. Jodee Rich regularly briefed board members before board meetings and remained instrumental in shaping up board members' views about One-Tel's performance (ASIC v. Rich, 2009, NSWSC 1229).

In summary, board composition and board activities in One.Tel suggest the following: (1) one of the joint-CEOs had excessive influence on the board; (2) board members received selective and incomplete information on crucial aspects of the business; (3) there was a lack of diversity of opinions in the board to scrutinise management; responsibilities were not clearly defined between the board and the management; and (5) the non-executive directors were virtually ineffective in providing a check and balance in the board. The above discussion leads to the following hypotheses:

$\mathrm{H}_{4}$ : Ceteris paribus, firms with weaker management scrutiny than others are more likely to collapse. 
$\mathrm{H}_{5}$ : Ceteris paribus, firms with poorer management communication to the board than others are more likely to collapse.

\subsection{Compensation}

Remunerating executives fairly and responsibly is part of good corporate governance practice (ASX CGC 2003). In 1998-99, the three executive directors and the board chair had a combined remuneration of A $\$ 2.3$ million. That year One-Tel reported an operating profit after tax of A\$6.97 million. For the year 1999-2000, remunerations paid to One-Tel’s five directors totalled A 15.5 million. This included a performance bonus of over A \$6.9 million paid to each of the two CEOs. This is the year when One-Tel reported a record loss of A \$291.1 million and when the share price was continually falling steeply since its peak of A \$2.84 on 26 November 1999. Over the next several months, One-Tel’s share price dropped to A $\$ 0.78$ on 30 September 2000. Thus, CEO compensation and firm performance were disjointed at One.Tel. Core et al. (1999) provide evidence that CEOs at firms with weaker governance structures receive greater compensation and firms with weaker governance structures perform worse than others.

Kedia and Philippon (2006) demonstrate that, in periods of suspicious accounting practice, firms make excessive investments and hire excessive number of employees to pool with high-quality firms. At the same time, managers exercise options in very large scales (Kedia and Philippon, 2006). One-Tel's directors had been granted options on very easy terms. In addition, they exercised options on a regular basis. In June 1998, Jodee Rich was holding four million share options in One-Tel (666 667 in his name and 3333333 through one of his companies). In November 1997, 3155000 options were granted to a number of employees and consultants to the company. On 30 June 1998, John Greaves (the board chair) acquired 1666666 shares by exercising his share options at A\$0.126 per share. On the same day, another 1666667 shares were issued to Inkwelo Pty Ltd (a company associated with John Greaves). One-Tel shares closed at A $\$ 2.72$ on 30 June 1998. As on 30 June 1998, a 
total of 9816667 options were held by 26 employees and directors of the firm of which 3 333333 options were held by Life Cell Pty Ltd (owned by Jodee Rich) and 2333333 options by Two Gables Pty Ltd (owned by Rodney Adler).

The 1999 Annual Report, released on 16 August 1999, stated that 30 million options had been granted to Brad Keeling over unissued ordinary shares with an exercise price of A \$1. Of these, 25 million options valued at A\$16 821 396, had the expiry date of 29 April 2001 and five million options valued at A\$3 934950 had the expiry date a year later. Similarly, Jodee Rich held 35 million options valued at A\$23 549944 with an exercise price of A\$1 and the expiry date of 29 April 2001. He held another 25 million options valued at A \$19 667748 with an exercise price of A\$1 and the expiry date 29 April 2002. Since 30 June 1998, One-Tel’s lowest share price was A \$0.98 on 15 July 1999 and on 16 August 1999, the share price was A $\$ 1.02$.

The 2000 Annual Report stated that options had been exercised to acquire 379586 570 shares in One-Tel Ltd at prices ranging from $\mathrm{A} \$ 0.0126$ to $\mathrm{A} \$ 1.00$. That is, the highest exercise price was more than 79 times of the lowest exercise price within a year or so. Similarly, 6666667 share options were exercised by One-Tel directors at a price of A\$0.0126 between 1 July 1999 and 16 August 1999. During 1999-2000, One-Tel’s top six executives were granted 8172688 share options valued at A\$15 857000 (exercise price of A \$1.11754 and expiry date of 1 Dec. 2004 for 2126936 options; the rest had the exercise price of A $\$ 1.53$ and expiry date of 1 Dec 2004). Thus, it appears that One-Tel was heavily engaged in granting options to its directors on very easy terms and conditions. In summary, the link between senior management compensation and One-Tel's performance appeared to be very weak.

The above discussion leads to the following hypothesis:

$\mathrm{H}_{6}$ : Ceteris paribus, firms with weaker executive pay-to-performance link than others are more likely to collapse. 


\section{Summary and conclusion}

This is a case study on the collapse of One-Tel, the fourth largest telecommunications company in Australia at the time of its collapse in May 2001. The company was set up in 1995 as a re-seller of Optus’ mobile phone service. Thus, its profit was determined by what it charged to its own customers and what it paid to Optus. The company hoped to attract customers by offering cheap mobile calling rates and selling profitable long distance and international call service to them. Around July 1996, tensions and disputes brewed between the two companies on issues of competition and promotion campaigns. In July 1997, One-Tel launched its discounted national and international calls using Global One’s network. The company was listed on the ASX on 12 November 1997.

One-Tel grew very rapidly in its early years in terms of the number of customers and sales revenue. It reported operating profit after tax of A\$3.7 (A \$7) million in 1996-97 (1998-99). In 1998, One-Tel expanded its operations to Europe and the US. In February 1999, News Ltd and PBL became major shareholders of One-Tel by investing close to one billion Australian dollars. On 23 November 1999, One-Tel was ranked as the 30th largest listed company in Australia with a market capitalisation of A $\$ 3.8$ billion. In August 2000, the company announced a record operating loss of A \$291 million for 1999-2000 fiscal year despite the doubling of sales revenue from the previous year to A\$654 million. In October 2000, the merchant bank Merrill Lynch warned that One-Tel was in danger of running out of cash. In February 2001, One-Tel reported a further loss of A \$132 million for July-December 2000. By April 2001, its cash balance had dropped to A $\$ 25$ million. On the last trading day of 25 May 2001, One-Tel shares closed at Australian 16 cents. The company went into receivership on 30 May 2001. Its creditors voted to wind up its operations on 24 July 2001.

The One-Tel collapse is a classic case of failed expectations, strategic mistakes, wrong pricing policy and unbridled growth. Clarke et al. (2003: 263) likened the collapse of One-Tel to ‘still-born' corporate trajectory. Hambrick and D’Aveni (1992) argue that 
corporate collapses are usually preceded by corporate deteriorations due to strategic errors of senior management. One-Tel management made strategic errors, too. One-Tel had wrong pricing policy. It got stuck in aggressive and costly customer acquisition campaigns. These customers did not contribute the revenues and the cash flows the company vitally needed to survive. It undertook a very aggressive strategy of expanding into new markets without consolidating its position in the existing markets. Time and again, One-Tel was involved in disputes with its suppliers (Optus and Telstra) and its network builder (Lucent Technologies). It paid dearly to acquire telecommunication licences to position itself in the market.

Nevertheless, the dream of building the leading phone company in Australia and the backing of the two Australian media magnates created high hopes in One-Tel investors, which led to 'market madness', but those high hopes were never realised. One.Tel had poor financial reporting quality including poor earnings quality. It was able to report small positive earnings in its early years due to non-conservative accounting policy choices and large positive accruals. It had weak internal controls and discrepancies in record keeping. Its audit quality was poor as well. It consistently received an unqualified audit opinion despite serious breaches of the Corporations Act, accounting standards and auditing standards in 1998. Despite One-Tel's worsening operating cash deficits, cash collection problems and losses concealed by non-conservative accounting policies, its auditor failed to issue any going concern opinion.

One-Tel management was able to paint a 'rosy' picture of the firm due to weak corporate governance. There was a lack of diversity of opinions in the board. The management did not make full disclosure to the board about the performance and solvency of the firm. On the other hand, the non-executive directors failed to scrutinise management effectively and ask 'awkward' questions to the management on how they operated the business. The link between executive pay and performance was weak in One.Tel. The management received larger performance bonuses in times of worsening firm performance. 
One-Tel had troubles with its cash balance, creditors, earnings, and debtors. However, management communications to the board always highlighted only EBITDA and gross margin, but not net profit. Further, the board was rarely apprised of aging creditors and aging debtor problems. Its cash balances reported in the board papers in most cases omitted unpresented cheques. There were no clearly defined responsibilities between the board and the management. One of the two joint-CEOs was very dominant in the board; this CEO never had to face an election subsequent to the first appointment and chaired several board meetings despite the presence of the board chair in those meetings. Although One-Tel had formed an audit committee, a remuneration committee, and even a corporate governance committee - all these committee roles were fulfilled by the same two non-executive directors. These committees appear to have had no impact on One-Tel's governance.

Firms with dominant CEOs perform worse in a turbulent environment (Haleblian and Finkelstein 1993). As late as 30 March 2001, One-Tel board meeting was told that ‘everything was fine’ (Barry 2002). Even later than that, on 1 May 2001, One-Tel’s cash crisis was simply termed as 'timing issue' (Barry 2002). To say the least, there was significant information asymmetry between One-Tel management and the shareholders during 2000 and 2001.

CEO dominance and poor monitoring of the management by the board stifled any chance for One-Tel's survival by blocking opportunities for board and leadership renewal. Further, CEO dominance, and major shareholders' excessive reliance on the CEOs for information allowed the CEOs to hide the true picture of the firm. All these factors together aggravated One-Tel’s crisis and led to its collapse.

One-Tel's collapse leaves several lessons on corporate strategies. First, it is not enough to acquire customers in large scale unless those customers contribute toward the profitability of the firm. Second, highly competitive pricing only to gain market share can 
have disastrous consequences. Third, it is not enough to generate sales revenues unless those revenues are collected in cash in a timely fashion.

One-Tel’s demise leaves several important lessons on corporate governance as well. First, strong internal controls, financial reporting quality, audit quality, effective management scrutiny, full disclosure of company affairs to the board, and a strong link between executive pay and firm performance are vital for effective corporate governance of a firm. Second, a board is less likely to detect firm problems when there is a dominant CEO in the firm. Third, non-executive board members should make their own enquiries into firm strategies and performance. Hence, non-executive members should be given access to middle and lower management to ensure transparency of information. Third, large investors in any firm must take an active interest in managing the firm. Fourth, as already documented in the literature, auditor's involvement in the non-audit service may compromise audit quality. Fifth, the board chair should always preside over the board meetings to control the board's agenda and to effectively monitor management behaviour.

This case study provides some new insights into the association between corporate collapse and corporate governance. In particular, all else being equal, firms with weaker corporate governance than others are more likely to collapse, and the demand for good governance heightens in the wake of poor firm performance. Thus, good corporate governance has the role of a 'safety net' against corporate collapse. 


\section{References}

Australian Broadcasting Corporation, 2001, '2001: The Year of Corporate Collapses' (Reporter: Alan Kohler), TV program aired on 21 December, transcript available at http://www.abc.net.au/7:30/content/2001/s445523.htm (accessed 4 March 2010)

ASX Corporate Governance Council, 2003, 'Principles of Good Corporate Governance and Best Practice Recommendations’, Sydney.

Australian Securities and Investment Commission v. Rich, 2009, New South Wales Supreme Court (NSWSC) 1229.

Agrawal, A. and Chadha, S. 2005, 'Corporate Governance and Accounting Scandals', The Journal of Law \& Economics, 48, 2: 371-406.

AAPT Annual Report, 1999, AAPT, Sydney.

AAPT Annual Report, 2000, AAPT, Sydney.

Barry, P., 2002, Rich Kids, Bantom Books, Sydney

Bhagat, S. and Bolton, B., 2008, 'Corporate Governance and Firm Performance', Journal of Corporate Finance, 14, 3: 257-73.

Brown, L. and Caylor, M., 2009, 'Corporate Governance and Firm Operating Performance', Review of Quantitative Finance and Accounting, 32, 2: 129-44.

Brown, L., and Caylor, M., 2006, 'Corporate Governance and Firm Valuation', Journal of Accounting and Public Policy, 25, 4: 409-64.

Carey, P. and Simnett, R. 2006, 'Audit Partner Tenure and Audit Quality', The Accounting Review, 81, 3: 653-676.

Charitou, A. and Neophytou, E. 2004, 'Predicting Corporate Failure: Empirical Evidence from the UK', European Accounting Review, 13, 3: 465-97.

Clarke, F. and Dean, G. 2007. Indecent Disclosure: Gilding the Corporate Lily. Cambridge University Press, Cambridge.

Clarke, F., Dean, G. and Oliver, K. 2003. Corporate Collapse: Accounting, Regulatory and Ethical Failure. Cambridge University Press, Cambridge.

Core, J.E., Holthausen, R.W. and Larcker, D.F. 1999, 'Corporate Governance, Chief Executive Officer Compensation, and Firm Performance', Journal of Financial Economics, 51, 3: 71-109.

Cooke, T. 2001, 'Collapse of Australia's Fourth Largest Telco Adds to a Growing List of Corporate Failures', available at World socialist Web Site: http:/www.wsws.org/articles/2001/jun2001/onte-jo8.shtml (accessed on 15 April 2010).

Cyert, R., Kang, S. and Kumar, P. 2002, 'Corporate Governance, Takeovers and TopCompensation: Theory and Evidence’, Management Science, 48, 4: 453-69. 
Dechow, P. M., Ge, W. And Schrand, C. 2010, 'Understanding Earnings quality: A Review of the Proxies, Their Determinants and Their Consequences', Journal of Accounting and Economics, 50, 2-3: 344-401.

Francis, J., Schipper, K. and Vincent, L. 2003, 'The Relative and Incremental Explanatory Power of Earnings and Alternative (to Earnings Performance Measures for Returns', Contemporary Accounting Research, 20, 1: 121-64.

Financial Accounting Standards Board (FASB), 2010, Statement of Accounting Concept No. 8. Available at http://www.fasb.org/cs/BlobServer?blobcol=urldata\&blobtable=MungoBlobs\&blobkey=id\& blobwhere=1175821997186\&blobheader=application\%2Fpdf. (Accessed on 8 August 2011)

Haleblian, J., and Finkelstein, S. 1993, 'Top Management Team Size, CEO Dominance, and Firm Performance: The Moderating Roles of Environmental Turbulence and Discretion', Academy of Management Journal, 36, 4: 844-63.

Hambrick, D., and D’Aveni, R. 1992, ‘Top Team Deterioration As Part of the Downward Spiral of Large Corporate Bankruptcies’, Management Science, 38, 10: 1445-1466.

Holstrom, B., and Kaplan, S. 2001, 'Corporate governance and merger activity in the United States: Making sense of the 1980s and 1990s', The Journal of Economic Perspectives,.15, 2: 121-44.

Houghton, K. 1984, 'Accounting Data and the Prediction of Business Failure: The Setting of Priors and the Age of data', Journal of Accounting Research, 22, 1: 361-68.

Hutchison Telecommunications (Australia) Ltd. Annual Report, 1999, Hutchison Telecommunications (Australia) Ltd., Sydney.

Hutchison Telecommunications (Australia) Ltd. Annual Report, 2000, Hutchison Telecommunications (Australia) Ltd., Sydney.

Jennings, M. 2003, 'EBIDTA, Ethics and Other Non-GAAP Measures', Corporate Finance Review, 8, 2: 39-43.

Jones, S. and Hensher, D. 2007, 'Modelling Corporate Failure: A Multinomial Nested Logit Analysis for Unordered Outcomes’, The British Accounting Review, 39, 1: 89-107.

Kedia, S. and Philippon, T. 2006, 'The Economics of Fraudulent Accounting', working paper, Rutgers University, USA.

King, A. 2001, 'Warning: Use of EBIDTA May be Dangerous to Your Career', Strategic Finance, 83, 3: 35-37.

Lennox, C. 1999, 'The Accuracy and Incremental Information Content of Audit Reports in Predicting Bankruptcy', Journal of Business Finance and Accounting, 26, 5-6: 757-78.

Lemmon, M., and Lins, K. 2003, 'Ownership Structure, Corporate Governance and Firm Value: Evidence from the East Asian Financial Crisis', The Journal of Finance, 58, 4: 1445468. 
Mäkelä, H. and Näsi, S. 2009, 'Social Responsibilities of MNCs in Downsizing Operations: A Finnish Forest Sector Case Analysed from the Stakeholder, Social Contract and Legitimacy Theory Point of View', Accounting, Auditing \& Accountability Journal, 23, 2: 149-74.

Mak, T., Deo, H. and Cooper, K. 2005, ‘Australia’s Major Corporate Collapse: Health International Holdings (HIH) Insurance 'May the Force Be with You', Journal of American Academy of Business, 6, 2: 104-12.

Mirshekary, S., Yaftian, A. and Cross, D. 2005), 'Australian Corporate Collapse: The Case of HIH Insurance’, Journal of Financial Services Marketing, 9, 3: 249-58.

McKinnon, J. 1988, 'Reliability and Validity in Field Research: Some Strategies and Tactics’, Accounting Auditing and Accountability Journal, 1, 1: 34-54.

Morey, M., Gottesman, A., Baker, E., Godridge, B., 2009, 'Does Better Corporate Governance Result in Higher Valuations in Emerging Markets? Another Examination Using a New Data Set', Journal of Banking and Finance, 33, 2: 254-71.

Ohlson, J. 1980, 'Financial Ratios and the Probabilistic Prediction of Bankruptcy', Journal of Accounting Research, 18, 1: 109-31.

One-Tel Annual Report, 1998, One-Tel, Sydney.

One-Tel Annual Report, 1999, One-Tel, Sydney.

One-Tel. Annual Report, 2000, One-Tel, Sydney.

Optus Annual Report, 1998, Optus, Sydney.

Optus Annual Report, 1999, Optus, Sydney.

Optus Annual Report, 2000, Optus, Sydney.

O.Shea, N. 2005, Governance: How we've got where we are and what's next. Accountancy Ireland, 37:33.

Owen, R. 2001, ‘Telco’s Creditors Vote for Wind up’, The Courier-Mail, 25 July: 4.

Shleifer, A., and R. Vishny, 1997, 'A Survey of Corporate Governance’, Journal of Finance 52, 737-783.

Stake, R. 1995, ‘The Art of Case Study Research', SAGE Publications, Thousand Oaks, California.

The Financial Times, 2000, 'Oz Back-packer with Packer as Backer Dreams Large: Rupert Murdoch is an Investor in One-Tel too', 16 June: 26. London edition).

Tregidga, H., and Milne, M. 2006, 'From Sustainable Management to Sustainable Development: A Longitudinal Analysis of a Leading New Zealand Environmental Reporter', Business Strategy and the Environment, 15, 4: 219-41. 
Yin, R. 2003, Case Study Research: Design and Methods $3^{\text {rd }}$ edition, Sage Publications, Thousand Oaks, California:. 
Table 1

Key performance indicators and characteristics of One-Tel

$1996-97$ to $1999-2000$

Number of customers at year-end (in '000)

Sales Revenue ( in $\mathrm{A} \$ \mathrm{~m}$ )

Operating profit after tax (in $\mathrm{A} \$ \mathrm{~m}$ )

Total operating cash flows (in A \$m)

Remuneration for the Board \& Top 5 executives (in A\$m)

Remuneration as a \% of Sales Revenue

Total remuneration to the auditor (A\$ '000)

Ratio of total fees to Revenues

Non-audit fees as \% of total fees

Audit report

Total assets year end (in $\mathrm{A} \$ \mathrm{~m}$ )

Shareholders' equity (in $\mathrm{A} \$ \mathrm{~m}$ )

Ratio of OPAT to Sales

Cash balance at end of year (A $\$ \mathrm{~m})$
1996-97

$1997-98$

1998-99

$1999-2000$

159

148.3

3.723

13.402

1.219

$0.82 \%$

59

$0.04 \%$

40.68\%

Unqualified

50.742

$-0.903$

0.03

2.783

290

207.3

5.910

$-8.000$

1.987

$0.96 \%$

120

$0.06 \%$

$54.17 \%$

Unqualified

78.199

28.161

0.03

8.403
642

326.0

6.965

$-28.945$

3.299

$1.01 \%$

169

$0.05 \%$

$52.07 \%$

Unqualified

525.967

363.030

0.02

172.641
730

653.400

$-291.100$

$-168.900$

17.070

$2.61 \%$

491

$0.08 \%$

$45.62 \%$

Unqualified

$1,435.500$

944.800

$-0.45$

-0.45
335.700 
Table 2

One-Tel's Cash Flows: 1996-97 to 1999-2000

(All figures are in $\mathrm{A} \$$ )

Cash received from customers

Cash paid to employees and

suppliers

Total operating cash flows

Cash flows from investing activities

Annual net expenditure on property,

plant and equipment

Purchase of licences

cash flows from financing activities

New equity issued during the year

New debt raised during the year

Dividends paid or provided during

the year

Cash balance at end of year

\begin{tabular}{rrrrr}
$1996-97$ to \\
$1996-97$ & $1997-98$ & $1998-99$ & $1999-2000$ & $1999-2000$ \\
\hline $113,161,000$ & $186,459,000$ & $300,135,000$ & $510,900,000$ & $1,110,655,000$ \\
$-98,708,000$ & $-193,348,000$ & $-328,108,000$ & $-684,800,000$ & $-1,304,964,000$ \\
$13,402,000$ & $-8,000,000$ & $-28,945,000$ & $-168,900,000$ & $-194,309,000$ \\
$-4,940,000$ & $-10,752,000$ & $-32,183,000$ & $-614,900,000$ & $-662,775,000$ \\
$-2,640,000$ & $-9,913,000$ & $-14,922,000$ & $-87,500,000$ & $-114,975,000$ \\
0 & 0 & $-9,500,000$ & $-525,600,000$ & $-535,100,000$ \\
$-10,891,000$ & $24,372,000$ & $226,244,000$ & $945,300,000$ & $1,185,025,000$ \\
0 & $25,764,000$ & $430,348,000$ & $818,500,000$ & $1,274,612,000$ \\
0 & 0 & $58,980,000$ & $139,800,000$ & $198,780,000$ \\
& & & & $10,085,000$
\end{tabular}


Table 3

Comparison of Performance Among One-Tel, Optus, AAPT and Hutchison

$\underline{1998}$

First year of providing telephony service

Total Assets (in A\$million)

Sales Revenue (in A\$million)

Operating profit after tax (in A\$million)

Debt to Asset ratio

Operating Profit after tax to Total Assets

Operating Profit after tax to Sales Revenue

OCF to Total Assets

Accruals to Total Assets

1999

Total Assets (in A\$million)

Sales Revenue (in A \$million)

Operating profit after tax (in A\$million)

Debt to Asset ratio

Operating Profit after tax to Total Assets

Operating Profit after tax to Sales Revenue

OCF to Total Assets

Accruals to Total Assets

2000

Total Assets (in A\$million)

Sales Revenue (in A\$million)

Operating profit after tax (in A\$million)

Debt to Asset ratio

Operating Profit after tax to Total Assets

Operating Profit after tax to Sales Revenue

OCF to Total Assets

Accruals to Total Assets

\begin{tabular}{rrrr} 
One-Tel & Optus & AAPT & Hutchison \\
\hline 1995 & 1992 & 1995 & 1999 \\
78.20 & $6,145.50$ & 341.70 & 56.20 \\
207.30 & $2,933.30$ & 464.00 & 258.40 \\
5.90 & -95.40 & -16.80 & 12.20 \\
0.64 & 0.71 & 0.69 & 1.44 \\
0.08 & -0.02 & -0.05 & 0.22 \\
0.03 & -0.03 & -0.04 & 0.05 \\
-0.10 & 0.05 & 0.08 & 0.33 \\
0.18 & -0.07 & -0.13 & -0.11 \\
& & & \\
526.00 & $6,760.10$ & 509.00 & 362.50 \\
326.00 & $2,451.00$ & 710.70 & 329.60 \\
7.00 & -8.10 & 29.50 & 2.30 \\
0.31 & 0.69 & 0.42 & 0.17 \\
0.01 & 0.00 & 0.06 & 0.01 \\
0.02 & 0.00 & 0.04 & 0.01 \\
-0.06 & 0.05 & 0.02 & 0.02 \\
0.07 & -0.05 & 0.04 & -0.01 \\
& & & \\
053.40 & $4,112.20$ & 891.30 & 404.70 \\
-291.10 & 264.30 & 38.20 & -92.50 \\
0.34 & 0.41 & 0.56 & 0.12 \\
-0.20 & 0.03 & 0.05 & -0.09 \\
-0.45 & 0.06 & 0.04 & -0.23 \\
-0.12 & 0.07 & 0.02 & -0.06 \\
-0.09 & -0.04 & 0.03 & -0.03
\end{tabular}


Flgure 1

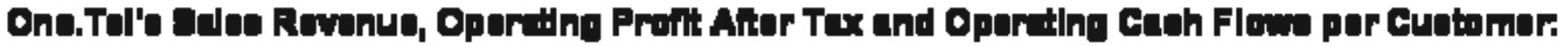
1003 to to $1000-2909$

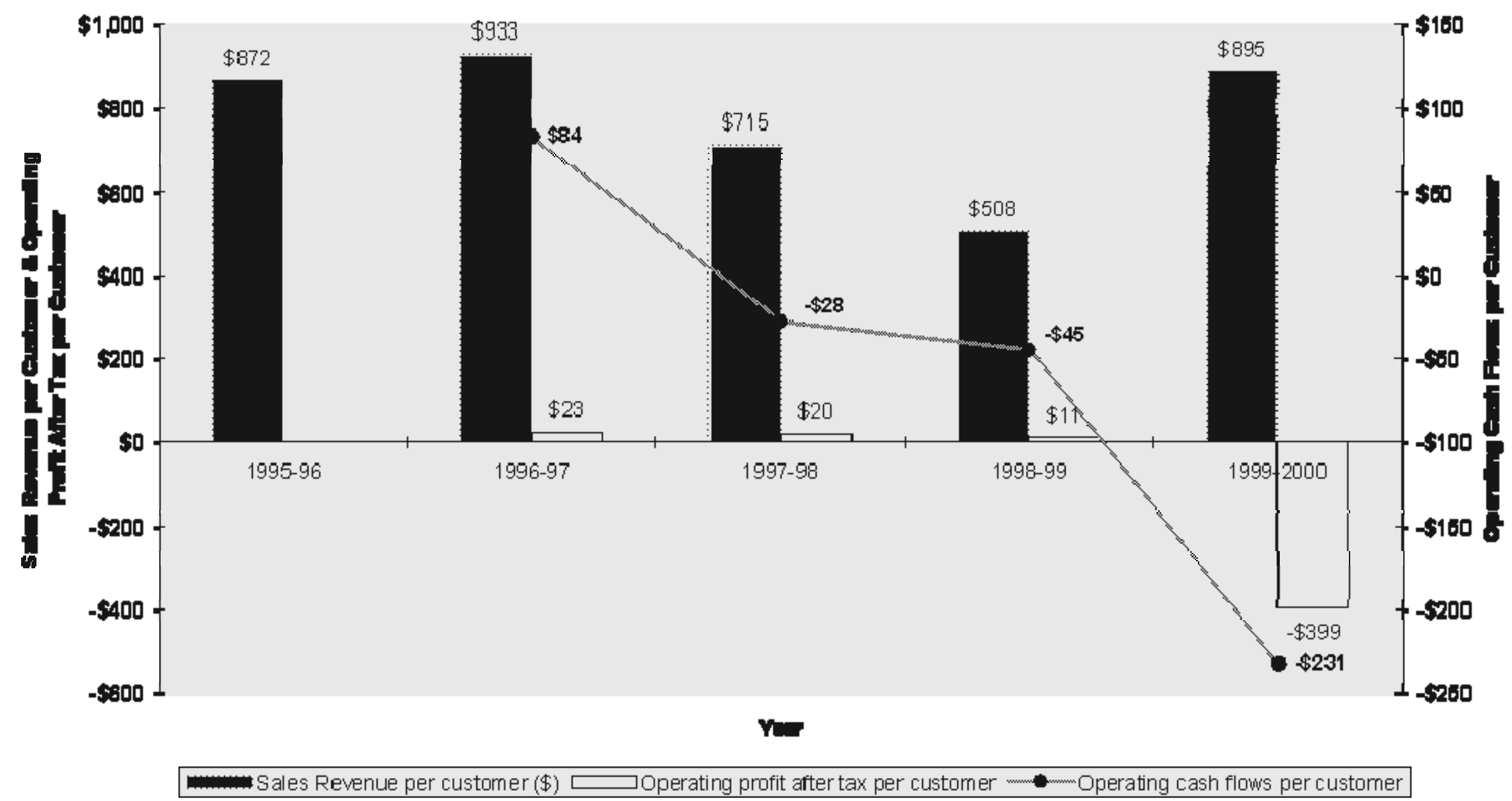




\section{Flourn 2}

Ona.Tal'e Guatomon, Daly Eales por Guatomor and Daly Oporiting Gash Flowe por Guatomor $1000-97$ to $1000-2000$

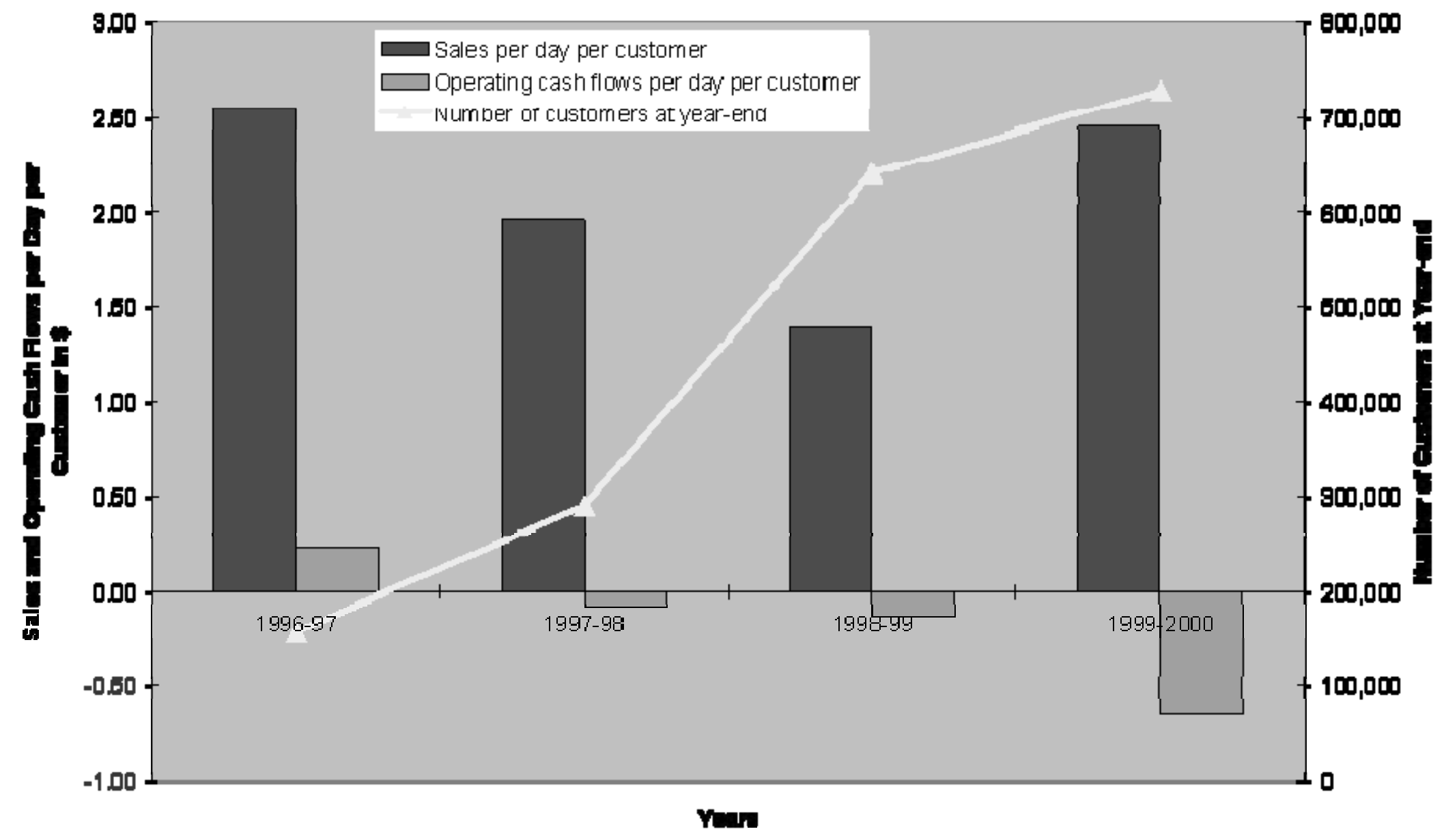




\section{Notes:}

${ }^{1}$ The exact name of the company was 'One.Tel.' The word 'One.Tel' has been replaced by 'One-Tel' throughout the text to avoid reader confusion with punctuations.

${ }^{2}$ One-Tel shares were subject to 10 for one split on 10 May 1999.

${ }^{3}$ One-Tel had July-to-June fiscal year, but it titled its annual reports as 1998 Annual Report, 1999 Annual Report and so on. Thus, the 1998 Annual Report refers to July 1997 -June 1998 fiscal year.

${ }^{4}$ Strictly speaking, only discretionary accruals are subject to management manipulation. Although total accruals of a growing firm can increase over time, a cross-sectional comparison of total accruals among firms of similar size within the same industry can shed some light on the quality of accruals in these firms (i.e., the extent of managed discretionary accruals). 